\title{
DOI https://doi.org/10.30525/978-9934-26-121-3-11
}

\section{ДЕМОКРАТИЗАЦІЯ ДЕРЖАВИ ЯК ЧИННИК ДОВГОСТРОКОВОГО РОЗВИТКУ УКРАЇНИ (НА ПРИКЛАДІ ПРАВООХОРОННОЇ ДІЯЛЬНОСТІ): ДЕРЖАВНО-УПРАВЛІНСЬКИЙ АСПЕКТ}

\author{
Максимова А. Я. \\ кандидат наук з державного управління, \\ провідний фахівеиь кафедри правоохоронної діяльності \\ та кримінально-правових дисииплін \\ Університету митної справи та фінансів \\ м. Дніпро, Украӥна
}

Розвиток суспільства та держави можливе лише в країні, що дотримується демократичних цінностей. Особа за таких умов здатна реалізовуватися та мати рівні можливості з усіма. Серед науковців немає однозначної думки щодо важливості демократії для створення середовища для розвитку особистості.

Раніше усталений консенсус говорив про те, що економічне зростання в принципі можливе і без демократизації. Більшість досліджень показували, що рівень демократизації навряд чи має позитивний або негативний вплив на економічне зростання.

Звичайно, економісти детально документували чимало існуючих переваг демократій, що стосуються їх здатності уникнення катастрофічних рішень, які часто трапляються в автократії. Наприклад, нобелівський лауреат 3 економіки і один 3 видатних дослідників в області бідності і голоду Амартія Сіна прийшов до висновку, що голод не може виникати при демократіях, i, більш того, всі історичні приклади масового голоду траплялися виключно в автократії.

Але незважаючи на те, що катастрофічно погані економічні рішення в демократіях трапляються рідше, в середньому, демократії розвивалися не набагато краще, ніж автократії.

Звичайно, прикладів успішних автократій безліч, але ще більше прикладів невдалих автократії. Якщо говорити мовою статистики, результати зростання автократії мають набагато більшу дисперсію, ніж історії зростання демократій.

У своїй роботі Гектор Алмейда і Данелія Феррейра показують, що варіація економічного зростання в автократії в 4,5 рази більше, ніж в демократіях. Якщо перекладати з мови статистики на людський, 
то в автократії різниця між показниками зростання в економічно «успішній» і «не успішній» країні в 4,5 рази більше, ніж в демократичних [1].

Підсумовуючи все вищенаведене, демократизація веде до повільного, але вірного зростання, а авторитаризм загрожує або швидким зростанням, якщо пощастить 3 лотереєю i до влади прийде компетентний автократ, або довгими роками бідності і несвободи, якщо не пощастить (що, звичайно, трапляється набагато частіше).

Джерелом консенсусу про невплив політичного ладу на економічний розвиток $є$ роботи гарвардського економіста Роберта Берроу, який, використовуючи регресійний аналіз, зробив висновок, що немає достатніх підстав вважати, що збільшення політичних прав веде до збільшення зростання економіки.

Забігаючи вперед скажу, що ця моя стаття про наукову роботу, яка була опублікована в 2019 році і яка спростовує висновки Берроу. По-справжньому зоряна команда, що складається 3 Дарона Аджемоглу 3 MTI, Суреша Найду 3 Колумбійського, Паскаля Рестрепо 3 Бостонського, Джеймса Робінсона з Чиказького університетів, опублікували статтю, в якій показують, що демократизація насправді $€$ причиною економічного зростання. Підвищення рівня демократизації веде до збільшення добробуту країни [1].

Отже, для створення сприятливого економічного середовища потрібно розвивати демократичні цінності, що в довгостроковій перспективі забезпечать зростання країні.

В Україні Верховна Рада та уряд, бажаючи створити економічно розвинену державу, мусять розвивати демократичні цінності. На сьогоднішній день, для успішного розвитку громадянського суспільства Україна має здійснити низку трансформацій у багатьох сферах взаємовідносин між громадянами та державою. Тому, нагальним стає розробка в Україні такої системи, яка б змогла визначати форми взаємодії представників правоохоронних органів i громадянського суспільства у перспективі, з урахуванням процесів формування соціальних умов та передумов, достатніх та необхідних для вирішення такої проблеми. Розвиваючи демократичну державу, доцільно розвивати громадянське суспільство та правоохоронну функцію держави як невід’ємного їі атрибуту.

Проблематика реалізації впливу громадянського суспільства на діяльність правоохоронних органів в Україні та його ролі у формуванні демократичного, євроінтегрованого державно-управлінського апарату вимагає всебічної та ретельної розробки нових методів та форм контрольно-ревізійної діяльності населення по відношенню до 
функціонування органів правопорядку, що мають бути виражені у надпозитивних суспільно-значущих зрушеннях у сфері прозорості та відкритості функціонування органів правопорядку, у відповідності до існуючих на сьогодні у країнах СС дієвих рекомендацій та покрокових інструкцій [2, с. 1].

Таким чином, правоохоронним органам необхідна тісна співпраця із громадянським суспільством 3 метою профілактики та нейтралізації неправомірних дій відносно держави та населення, задоволення людських потреб у частині безпеки повсякденного життя. Така ситуація зумовлена наявністю взаємозалежності та взаємного впливу інститутів державного управління та громадянської спільноти. Виходячи із вище викладеного, дійдено висновку, що взаємодія громадського сектору та представників правоохоронних органів представляє собою процес, в якому ефективність забезпечення правопорядку та надання допомоги громадянам мають пряму залежність від підтримки суспільством правоохоронних органів шляхом визначення соціальних стандартів громадського правопорядку [2, с.7].

Отже, неодмінним атрибутом розвитку України $\epsilon$ формування демократичних цінностей. Головною передумовою для розвитку демократичної спільноти є функціонування громадянського суспільства та забезпечення правоохоронної функції держави.

\section{Література:}

1. Демократизация - причина экономического роста URL.: https://www.gazeta.uz/ru/2020/12/29/democratization/ https://www.gazeta.uz/ ru/2020/12/29/democratization/ (дата звернення: 10.07.2021)

2. Кива І.В. Механізми впливу громадянського суспільства на державне регулювання правоохоронної діяльності (на прикладі країн СС та України): автореф. дис. ... канд.н.держ. упр. : 25.00.02 / Міжрегіон. акад. упр. перс. Київ, 2021. 21 с. 